\title{
Investigates the Impact of Social Media Influencers' Personality, Content, and Trustworthiness on Consumers' Purchase Intention and eWOM
}

\author{
Kholod Khalid Aggad, Fauziah Sh Ahmad
}

To Link this Article: http://dx.doi.org/10.6007/IJARBSS/v11-i12/11782

DOI:10.6007/IJARBSS/v11-i12/11782

Received: 08 October 2021, Revised: 11 November 2021, Accepted: 27 November 2021

Published Online: 20 December 2021

In-Text Citation: (Aggad \& Ahmad, 2021)

To Cite this Article: Aggad, K. K., \& Ahmad, F. S. (2021). Investigates the Impact of Social Media Influencers' Personality, Content, and Trustworthiness on Consumers' Purchase Intention and eWOM. International Journal of Academic Research in Business and Social Sciences, 11(12), 2368-2384.

Copyright: (c) 2021 The Author(s)

Published by Human Resource Management Academic Research Society (www.hrmars.com)

This article is published under the Creative Commons Attribution (CC BY 4.0) license. Anyone may reproduce, distribute, translate and create derivative works of this article (for both commercial and non0-commercial purposes), subject to full attribution to the original publication and authors. The full terms of this license may be seen at: http://creativecommons.org/licences/by/4.0/legalcode

Vol. 11, No. 12, 2021, Pg. 2368- 2384

Full Terms \& Conditions of access and use can be found at http://hrmars.com/index.php/pages/detail/publication-ethics 


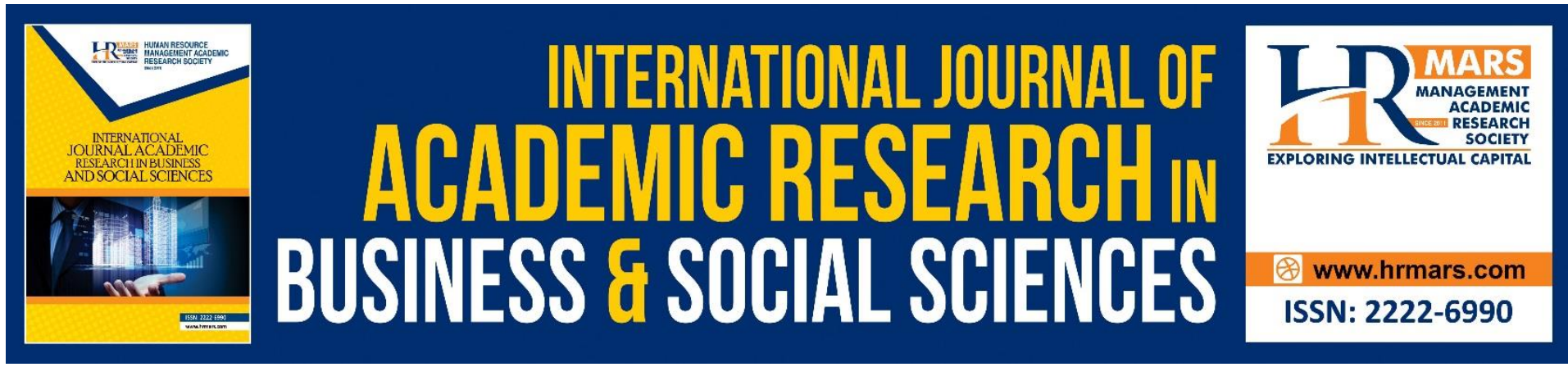

\title{
Investigates the Impact of Social Media Influencers' Personality, Content, and Trustworthiness on Consumers' Purchase Intention and eWOM
}

\author{
Kholod Khalid Aggad, Fauziah Sh Ahmad \\ Azman Hashim International Business school Universiti Teknologi Malaysia, College of \\ Business Administration, University of Business and Technology, Jeddah, Saudi Arabia
}

\begin{abstract}
Social media influencer marketing is a form of social media marketing involving product placement and endorsements from influencers. Influencers successfully shape consumers' perceptions towards products or services by posting videos, content, or pictures on their social media channels. However. We proposed this study to investigate the impact of social media influencers' personality, content, and trustworthiness on consumers' purchase intention and eWOM towards different brands in Saudi Arabia. We applied a quantitative research method to carry this study. Therefore, an online questionnaire was developed to gather data from 510 respondents using non-probability. To obtain the study objectives, we analyzed the primary data using structural equation modeling via SmartPLS software. The results reveal that social media influencers' personality, content, and trustworthiness significantly impact consumers' purchase intention and eWOM. This study results help brands, advertisers, and marketers to understand how social media influencers' marketing techniques can influence consumers' purchase intention and eWOM towards different brands. Thus, it will also support them to know the key factors that could significantly explain consumers' intention and eWOM towards social media influencers. Further, this study purpose of investigating the influence of social media influencers on the consumers' purchase intention in different sectors and context.
\end{abstract}

Keywords: Social Media Influencers, Personality, Content, Trustworthiness, Purchase Intention, Ewom, Saudi Arabia

\section{Introduction}

The technological revolution has been significantly changing the way of communication, either formal or informal (Licoppe and Smoreda, 2005; Pratt et al., 2012). From that, social media is one of the prominent inventions (Weaver et al., 2012). Several companies continuously use social media to communicate with customers and develop product promotion strategies based on the customers' feedbacks on social media channels (Carr and Hayer, 2015; lankova et al., 2019). Thus, most companies use social media platforms for marketing purposes (Chatterjee and Kar, 2020). With the popularity of social media, it is easy 
and reliable to approach maximum customers in a limited duration and budget (Zuhdi et al., 2019). According to Abbas et al (2019), brands are achieving the objective of relationship marketing and also enhancing brand value through the social media marketing campaign. The most famous platforms are Instagram, YouTube, Facebook, Snapchat, Twitter, etc. The massive popularity of social media globally can be well known because currently, 3.78 billion users use different social media channels to communicate (Bhattacharyya et al., 2021; Cole et al., 2021; Almalki et al., 2021).

However, the constantly increasing number of social media users introduced a new kind of digital media marketing, called "Social Media Influencer Marketing" (Singh et al., 2020; Shan et al., 2020; Zhou et al., 2021). In this regard, it is common now for companies to hire famous social media celebrities to endorse their services and products promotion through social media platforms (Glucksman, 2017). Eventually, social media influencers are typical individuals who become famous on different social media channels by creating and posting content on various topics such as technology, entertainment, tourism, fashion, education, reviews, sports, etc. (Rishika et al., 2013; Kim et al., 2020; Singh et al., 2020; Reagan et al., 2020). According to Zhou et al (2021), social media influencers exemplify a novel independent third-party endorser who significantly influences consumers' attitudes and intentions through creative content towards a brand.

Influencers develop products and services promotion strategies in several formats, such as videos, photos, and blogs (Shan et al., 2020). Hence, Hu et al (201) reported that social media influencers and followers connect based on their trust and personality. Also, companies believe and getting maximum return from the marketing campaign by the influencer (Singh et al., 2020). In this regard, the social media influencer has been mutating the marketing trends following the modern marketing era (Kim et al., 2020). "The social media is crowded with the presence of people having experience in diverse fields, and thus, using social media influencers for marketing communication has emerged as an efficient and valuable means for the brands" (Saima and Khan, 2020 p.2). Glucksman et al (2017) stated that this kind of marketing campaign might be very effective in making a long-term relationship with the brands looking to develop their consumer base and convert them into lasting customers.

Therefore, several companies developed their social media accounts on different channels for product promotions. Still, only a few got followers' attention to their brands; most form them failed to gain the maximum consumers' attention (Huhmann and Limbu, 2016). Thus, companies are now paying more attention to hiring an experienced and knowledgeable social media influencer who could attract maximum followers towards their brands (Kim et al., 2020). However, several studies pointed out that social media influencers significantly impact consumers purchase intention and eWOM intention in developed countries (Jiménez-Castillo and Sánchez-Fernández, 2019; Rosara and Luthfia, 2020; Guping et al., 2021; Plidtookpai and Yoopetch, 2021; Muda and Hamzah, 2021), yet research on social media influencer marketing in Gulf Cooperation Council (GCC) is still scant (Hurley, 2019).

Prior studies have examined how numerous features of traditional media marketing techniques impact consumers' purchase intention and eWOM (Kala and Chaubey, 2018; Sulthana and Vasantha, 2019). Thereby, few research studies shed light on the impact of influencer marketing on consumer purchase intention (Kay et al., 2020). However, the current 
study aims to investigate the impact of social media influencers' personality, content, and trustworthiness on consumer purchase intention and eWOM in GCC countries, mainly Saudi Arabia.

We are presenting the practical and academic need to expand the research and the development argument on the potential influence of social media influencers. However, we develop a research model regarding the convincing influence of influencers' personality, content, and trustworthiness on their followers. The model investigates whether influencers' personality, content, and trustworthiness can impact consumers' purchase and eWOM intention towards the brands endorsed by the influencers. Therefore, we used the theory of reasoned action to develop the conceptual model for this study.

\section{Theoretical and Hypothesis Development}

Researchers widely use the theory of reasoned action to understand and predict individuals' attitudes and behavior (Vallerand et al., 1992; Hale et al., 2002). The critical aim of the theory is to explain individuals' beliefs, trust, and motivational influences on their behavior and intention towards a product or service (Sheppard et al., 1988; Madden et al., 1992). Thus, prior scholars use the theory to predicate internal factors, i.e., individuals' perceptions of objects or events, and external factors, i.e., social influences, affect individuals' intentions to perform a particular behavior (Ham et al., 2014). According to Madden et al (1992), the theory of reasoned action educates the companies on understanding the individual's behavior towards their products or services. Mainly, this theory predicates the individuals' behavior towards products based on their past experiences (Hale et al., 2002). Another study by sarver (1983) pointed out that the individuals' past attitudes predicate their present behavior towards a brand.

Empirically, several marketing and advertising research studies reported that the theory of reasoned action significantly predicator consumers' intention towards marketing a product or services (Pookulangara et al., 2011; Lee et al., 2013; Ham et al., 2014; Kim et al., 2020). Therefore, Ham et al (2014) concluded that individuals' attitudes towards social media influencers are influenced by their trust and belief in this theory. Accordingly, Kim et al (2020) noted that using this theory is valuable to know the actual intention of consumers towards the contents of influencers. However, content by influencers plays an essential role in building strong relationships with their followers (Confente and Vigolo, 2018; Jones, 2020). Hence, influencers' personality is also a dynamic factor influencing followers' purchase intention towards the brands they advertise on their different social media channels (Ahmad and Bruno, 2021).

Additionally, social media influencers' creative content and personality maximize their interaction with followers, which ultimately enhances the sales of products or services they post on their social media timelines (Jones, 2020). Considering the advancement of the current digital marketing era, companies should switch from traditional to modern marketing techniques to effectively approach targeted audiences (Kim et al., 2020). From that, social media influencers' marketing getting highlighted by several scholars (Confente and Vigolo, 2018), which significantly earned the highest rank in the marketing world. This study aimed to investigate the impact of social media influencers' content, personality, and trustworthiness on the consumers' purchase intention and eWOM. To obtain the study's 
objective, we used the theory of reasoned action to predicate the consumers' purchase intention and eWOM through social media influencers.

\section{Hypothesis Development}

\section{Personalities of Influencers and Purchase Intention and eWOM}

Recently research studies concluded that the influencer's personality is one of the most imperative factors when individuals follow social media influencers (Chu and Chen, 2019; Yusuf and Busalim, 2018). Zeng and Seock (2019) mentioned that the attractive personality of an influencer immediately affects follower perception, and it also leads to followers' positive intention toward a brand. Increasing the number of followers is the all-time stress of influencers. They used to adopt different moral and great-looking personalities trends (Confente and Vigolo, 2019). More likely, influencers' purpose is to attract maximum followers towards the brand they do advertise on their channel (Tien et al., 2019), which ultimately impacts consumers' purchase intention (Tien et al., 2019) and eWOM (Chu and Chen, 2019). According to Dhanesh and Duthler (2019), influencers' personality is essential in developing consumers' positive purchase intention towards brands (Slamet, 2019). Similarly, Zeng and Seock (2019) pointed out that every company chooses influencers considering their targeted consumers' needs and class, for example, food, beauty, sports, travel, etc., all have a different style of followers, and they always follow the modern trends and adopt in their personality as could entertain the followers (Slamet, 2019).

Therefore, several studies investigated the association between social media influencers' personalities and consumers' purchase intention (Tien et al., 2019) and eWOM (Chu and Chen, 2019). Most of them found a strong and positive association between them. Saima and Khan (2020) conducted a quantitative study and found influencers' personality significantly impacts the consumers' purchase intention towards brands they advertise. In addition, Tien and Rivas (2019) concluded that the positive eWOM of consumers shows their loyalty to the brand. Hence, some consumers are inspired by the influencers' personalities and start doing eWOM. Thus, they positively linked with each other. On the other hand, social media influencers are still a novel term for several companies in developing countries, mainly Saudi Arabia (Al-Nasser and Mahomed, 2020; Ahmed et al., 2021). Therefore, the present study aims to find an association between influencers' personalities, consumers' purchase intention, and eWOM. Thus, we developed the following hypotheses:

H1: Personality of influencers positively associated with consumers' Purchase intention $\mathrm{H} 2$ : Personality of influencer positively associated with consumers' eWOM intention

\section{Content by Influencer, Purchase Intention, and eWOM}

Experience and knowledge in a given domain support social media influencers to compose effective content such as pictures, videos, or blogs (Arriagada and Ibáñez, 2020; Ozgen and Mahmoudian, 2021). Influencer content support to create collaboration with brands and expertise in the subject matter. The purpose of producing unique content is to reach larger and new audiences by leveraging those influencers' potential credibility and social followings (Stubb and Colliander, 2019). Influencers' content induces the strong belief that their messages are informative and valid (Zeng and Seock, 2019). Influencers' informative and timely content significantly impacts consumers' purchase intention (Saima and Khan, 2020). 
Anchoring to the effect of influencers' content, it is imperative to create a positive message which must not hit any culture, religion, or political ethics (Nisa, 2018).

However, prior studies examined the relationship between influencers' content and consumers' purchase intention (Weismueller et al., 2020) and eWOM (Zhou et al., 2021). In this regard, Saima and Khan (2020) carried out a study in India and found content by influencers significantly impacts consumer purchase intention. Another survey by Rothe and Wicke (2018) found eWOM of consumers positively affected by influencers' content. According to Bonnevie et al (2020), a lack of information and skills of influencers can minimize their credibility among followers. Plus, Zhou et al (2021) suggested that they should analyze the current market trends and create content accordingly, ensuring the strong belief of followers in influencers and the brands they advertise.

Empirically, it is confirmed that influencers' content positively impacts consumers' purchase intention and eWOM (Weismueller et al., 2020). Content is a dominant factor of influencers that could shape consumers' awareness of a brand. However, Rothe and Wicke (2018) pointed out that the researchers still need to illustrate the association between these main constructs in developing countries. Thus, we developed the following hypotheses to confirm that relationship quantitatively:

H3: Content by influencer positively associated with consumers' Purchase intention H4: Content by influencers positively associated with consumers' eWOM intention

\section{Trustworthiness of Influencers, Purchase Intention, and eWOM}

Lou and Yuan (2019) have defined the trustworthiness of an influencer as the perception of individuals based on sincerity, honesty, or truthfulness. However, several other factors of trustworthiness have been recognized by scholars recently, from that they emphasized that trustworthiness is still a critical factor of influencers. The trustworthiness of influencers significantly impacts consumers' perceived credibility, information (Chekima et al., 2020; Nafees et al., 2020), purchase intention, and eWOM (Tien et al., 2019; Plidtookpai and Yoopetch, 2021). Thus, this also affects consumers' attitudes towards making a purchase decision (Weismueller et al., 2020). Characteristics of trustworthiness can be predicated on keeping promises and being honest (Bonnevie et al., 2020).

However, recently several studies found a strong positive relationship between social media influences trustworthiness, purchase intention, and eWOM in developed countries (Tien et al., 2019). Thereby, limited researchers investigate the relationship between influencers' trustworthiness, purchase intention (Plidtookpai and Yoopetch, 2021), and eWOM in developing countries. Thus, we developed the following hypotheses:

H5: Trustworthiness of influencers positively associated with consumers' Purchase intention H6: Trustworthiness of influencers positively associated with consumers' eWOM intention

\section{Methods}

\section{Measurement}

To obtain the current study's aim, we developed measurement items, and all were adopted from the previous studies and modified some. For example, items for the personality of 
influencer were adapted from (Pornsrimate and Khamwon, 2020; Gunnarsson et al., 2018), content by the influencer (Yoo et al., 2016), trustworthiness by the influencer (Wiedmann and Von Mettenheim, 2020), consumers' purchase intention (Kudeshia and Kumar, 2017), and eWOM (Prayogo et al., 2016). Therefore, we used a Likert scale 5-point ranging (1=strongly disagree to $5=$ strongly agree) to evaluate the different constructs of this study, and all respondents were requested to evaluate each item using that scale. According to Pescaroli et al (2020), social and management science studies widely use the Likert scale to conduct quantitative research. Thus, demographic and basic questions were presented in the first section of the questionnaire (see Table 1 and Table 2).

\section{Sample and Data Collection}

As in Jun 2021, a report published by Global Media Insight pointed out that in Saudi Arabia total of 33.58 million users are using different social media channels, i.e., YouTube 31.40 million (89.50\%), Instagram 26.80 million (76.40\%), Facebook 25.92 million (73.90\%), Twitter 25.05 million (71.40\%), Linkedln 13.96 million (39.80\%), Pinterest 10.21 million (29.10\%), and Tumblr 6.24 million (17.80\%), and the number of social media users is constantly increasing (GMI, 2021), considering these higher number of social media users encouraged us in the selection of a sample. Thus, we collected data from random customers visiting different shopping malls in Saudi Arabia.

Table 1. Demographic information and Basic Questions

\begin{tabular}{|c|c|c|}
\hline Indicators & Frequency & Percent \\
\hline \multicolumn{3}{|l|}{ Gender } \\
\hline Male & 170 & 11.8 \\
\hline Female & 340 & 88.2 \\
\hline \multicolumn{3}{|l|}{ Age (in the year) } \\
\hline $18-25$ & 123 & 24.11 \\
\hline $26-32$ & 124 & 24.31 \\
\hline $33-40$ & 128 & 25.09 \\
\hline Above 41 & 135 & 26.47 \\
\hline \multicolumn{3}{|l|}{ Education level } \\
\hline High school & 94 & 18.43 \\
\hline Bachelor & 197 & 38.62 \\
\hline Masters & 180 & 35.29 \\
\hline Doctorate & 14 & 2.74 \\
\hline Other & 25 & 4.90 \\
\hline \multicolumn{3}{|l|}{ What is your monthly income? } \\
\hline SAR 1,001 to 2,000 & 108 & 21.17 \\
\hline SAR 2,001 to 3,000 & 156 & 30.58 \\
\hline SAR 3,001 to 4,000 & 104 & 20.39 \\
\hline More than SAR 4,001 & 142 & 27.84 \\
\hline \multicolumn{3}{|c|}{ Select the following social media channel you usually use? } \\
\hline Facebook & 230 & 45.09 \\
\hline Instagram & 160 & 31.37 \\
\hline YouTube & 108 & 21.17 \\
\hline Twitter & 12 & 2.35 \\
\hline
\end{tabular}


In this regard, we used a nonprobability sampling method. The questionnaires were shared through a web link, and the principal investigator guided the participant on the understanding of items if they did not understand some. Our sample comprised Saudis with knowledge about social media influencers, the motivation why a qualifying question was pasted at the first section of the questionnaire to exclude respondents with no familiarity with social media influencers. A total of 539 respondents successfully returned the filled questionnaire. About 510 valid responses were considered (94.61\%), while 29 were excluded for ticking the same answers for all items and lack of knowledge about social media influencers. We processed to test reliability, validity, and hypotheses testing.

\section{Results}

"Structured equation modeling" (SEM), based on a "confirmatory factor analysis," has been carried out to test direct relationships between the constructs and validate the measurement model for this study. According to Saleem et al. (2021), SEM via smartPLS is an advanced statistical approach to test a quantitative model. The proposed research model for the current study was assumed to be complex, so we determined the use of the "partial least squares" (PLS) technique as it is the most usable and fit method for quantitative research models. The following section investigates the measurement of a model to obtain construct reliability, indicator reliability, discriminant validity, and convergent validity via SmartPLS software.

\section{Measurement Model}

As presented in Table 2, in this study, we tested factor loading for measurement items. We found all items have loadings values above 0.6, confirming that the factor loading is determined (Sarstedt and Cheah, 2019). To check the reliability and validity of constructs, we used "composite reliability" (CR) values shown in Table 3 presents that all constructs have CR $>0.7$, guaranteeing the reliability of constructs were achieved (Ramayah et al., 2017). Hence, the convergent validity was evaluated using the "average variance extracted" (AVE); for all the constructs, the AVE value suggested above 0.5 , confirming the achievement of convergent validity for the measurement model (Ramayah et al., 2018). 
Table 2. Measurement Items

\begin{tabular}{lll}
\hline Constructs & Items code & Loading \\
\hline \multirow{2}{*}{ Personality by Influencers } & PINF1 & 0.712 \\
& PINF2 & 0.772 \\
& PINF3 & 0.726 \\
\hline \multirow{3}{*}{ Content by Influencers } & COINF1 & 0.657 \\
& COINF2 & 0.774 \\
& COINF3 & 0.794 \\
Trustworthiness of Influencer & COINF4 & 0.785 \\
& COINF5 & 0.789 \\
& COINF6 & 0.653 \\
\hline & TRINF2 & 0.852 \\
Purchase Intention & TRINF3 & 0.894 \\
eWOM & TRINF4 & 0.890 \\
& TRINF5 & 0.839 \\
\hline & PINT1 & 0.797 \\
& PINT2 & 0.760 \\
& PINT3 & 0.849 \\
& PINT4 & 0.813 \\
& PINT5 & 0.830 \\
\hline
\end{tabular}

Table 3. Validity and Reliability of Constructs

\begin{tabular}{llll}
\hline & Alpha & $\begin{array}{l}\text { Composite } \\
\text { Reliability }\end{array}$ & $\begin{array}{l}\text { Average Variance } \\
\text { Extracted }\end{array}$ \\
\hline Personalities of Influencers & 0.682 & 0.832 & 0.543 \\
Content by Influencers & 0.838 & 0.881 & 0.555 \\
Trustworthiness of Influencers & 0.908 & 0.931 & 0.731 \\
Purchase Intention & 0.869 & 0.905 & 0.657 \\
e Word of Mouth & 0.822 & 0.883 & 0.656 \\
\hline
\end{tabular}

Next, the "discriminant validity" was checked using Fornell and Larcker (1981), which highlighted the root square of AVE for each latent variable suggested to be higher than the correlation with any other latent variable as presented in Table 4. Thereby, the evaluation of the convergent validity, construct reliability, and indicator reliability shows satisfactory findings, validating that the constructs of this study can be used to test the proposed study model. 
Table 4. Discriminant validity

\begin{tabular}{llllll}
\hline & $\mathbf{1}$ & $\mathbf{2}$ & $\mathbf{3}$ & $\mathbf{4}$ & $\mathbf{5}$ \\
\hline Content by Influencers & $\mathbf{0 . 7 4 5}$ & & & & \\
Personalities of Influencers & 0.498 & $\mathbf{0 . 7 3 7}$ & & & \\
Purchase Intention & 0.613 & 0.476 & $\mathbf{0 . 8 1 0}$ & & \\
Trustworthiness of Influencers & 0.568 & 0.413 & 0.528 & $\mathbf{0 . 8 5 5}$ & \\
e Word of Mouth & 0.476 & 0.386 & 0.635 & 0.472 & $\mathbf{0 . 8 1 0}$ \\
\hline
\end{tabular}

\section{Structural Model}

We used bootstrapping of 5000 subsamples to test the statistical significance of path coefficients (Ringle et al., 2020). Accordingly, Saleem et al. (2021) suggested that the key criterion for evaluating the structural model is the coefficient of determination $\left(R^{2}\right)$ of the endogenous latent variables (see Figure 1 ). The results show that $44.9 \%$ of the variation in the purchase intention and $30.4 \%$ for eWOM.

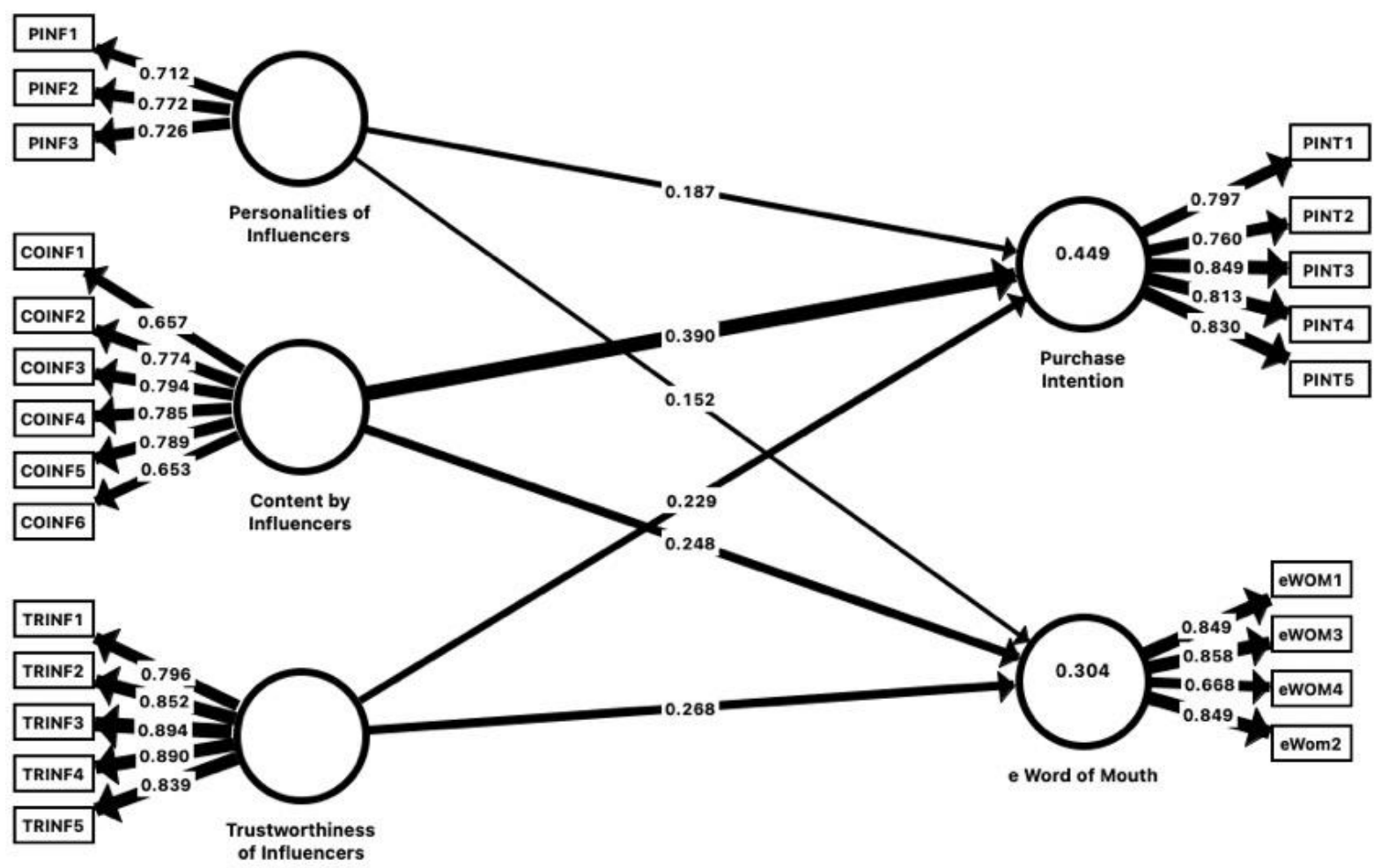

Figure 1. Structural Model for Social Media Influencers

Hypothesis 1 of personality of influencers to purchase intention $(\beta=0.187 ; p$-value $=0.000)$, hypothesis 2 of personality of influencers to eWOM $(\beta=0.152, p$-values 0.001$)$, hypothesis 3 of content by influencers to purchase intention $(\beta=0.390, p$-values $=0.000)$, hypothesis 4 of content by influencers to eWOM ( $\beta=0.248, p$-values 0.000$)$, hypothesis 5 of trustworthiness of purchase intention $(\beta=0.229, p$-value $=0.000)$, hypothesis 6 to trustworthiness of influencers to eWOM $(\beta=0.268, p$-values $=0.000)$. Thus, statistical results show all hypotheses are statistically significant, further see Table 5$)$.

In results summary, six hypotheses were developed, all of them show significant results, which illustrate that the social media influencers' personality, content, and trustworthiness positively impact consumers' purchase intention and eWOM. 
Table 5. Path coefficient

\begin{tabular}{|c|c|c|c|c|}
\hline & $\begin{array}{l}\text { Original } \\
\text { Sample } \\
\text { (0) }\end{array}$ & $\begin{array}{l}\text { Sample } \\
\text { Mean (M) }\end{array}$ & T Statistics & P Values \\
\hline $\begin{array}{l}\text { Personalities of Influencers } \rightarrow \\
\text { Purchase Intention }\end{array}$ & 0.187 & 0.189 & 4.383 & 0.000 \\
\hline $\begin{array}{l}\text { Personalities of Influencers } \rightarrow \mathrm{e} \\
\text { Word of Mouth }\end{array}$ & 0.152 & 0.154 & 3.388 & 0.001 \\
\hline $\begin{array}{l}\text { Content by Influencers } \rightarrow \\
\text { Purchase Intention }\end{array}$ & 0.39 & 0.391 & 8.713 & 0.000 \\
\hline $\begin{array}{l}\text { Content by Influencers } \rightarrow \text { e } \\
\text { Word of Mouth }\end{array}$ & 0.248 & 0.249 & 5.141 & 0.000 \\
\hline $\begin{array}{l}\text { Trustworthiness of Influencers } \\
\rightarrow \text { Purchase Intention }\end{array}$ & 0.229 & 0.228 & 5.014 & 0.000 \\
\hline $\begin{array}{l}\text { Trustworthiness of Influencers } \\
\rightarrow \text { e Word of Mouth }\end{array}$ & 0.268 & 0.27 & 5.632 & 0.000 \\
\hline
\end{tabular}

\section{Discussion}

\section{Theoretical Implications}

The current study has two theoretical implications. First, consumers' purchase intention and eWOM are positively influenced by influencers' personality, content, and trustworthiness linked with previous studies (Prayogo et al., 2016; Gunnarsson et al., 2018; Pornsrimate and Khamwon, 2020). Content by influencer and trustworthiness was the most substantial factor affecting consumers' purchase intention and eWOM, while influencers' personality had the moderating impacts on consumers' eWOM. These findings reveal that an influencer with creative content and trustworthiness is more probably to influence the consumers' purchase intention and eWOM, as suggested by recent studies (Zhou et al., 2021; Ahmed et al., 2021; Saima and Khan, 2021).

Second, this study's results explain that the variation in consumers' purchase intention can be more described by social media influencers' personality, content, trustworthiness (Chekima et al., 2020). These statistical findings imply that social media influencers impact consumers' purchase intention towards a particular brand and influence eWOM intention. These theoretical implications suggest that social media influencer marketing is the best alternative for brands aiming to enhance awareness about their products, services offerings, maximize market share and create potential purchase intention among new and existing customers.

\section{Practical Implications}

The statistical findings of the current study allow us to draw main practical implications. Personality, content, and trustworthiness are the main factors customers notice when following social media influencers. Accordingly, companies and advertising agencies can concern and adopt influencer marketing techniques to promote their brands to a wide range of audiences.

\section{Limitations and Future Research}

Discussing interesting theoretical and practical implications, current research is still subject to some limitations. First, the primary data was gathered using non-probability sampling, yet 
the adoption of a probability sampling method was unrealizable in our study. Second, the study was carried out with consumers from only one city in Saudi Arabia. Studies are to be carried in different contexts to overcome cultural and social similar kinds of research to compare results. Finally, it would be interesting if future researchers could have a qualitative study to investigate the impact of social media influencers on consumers' attitudes and purchase intention.

\section{Conclusions}

The main contribution of the current study was to identify the key factors of social media influencers and their impact on the consumers' purchase intention and eWOM. In this regard, we developed a conceptual framework based on a theory of reasoned action for social media influencers. Thus, for the conceptual framework, we adapted other variables from previous studies. Our research presents the direct impact of social media influencers' personality, content, and trustworthiness on consumers' purchase intention and eWOM towards brands in Saudi Arabia. To obtain this objective, we collected data from 510 random customers visiting different shopping malls in Jeddah, Saudi Arabia; empirically, we found that consumers' purchase intention and eWOM are significantly influenced by social media influencers personality, content, and trustworthiness, as previous studies in different contexts also identified it. However, we found that the content and trustworthiness of influencers strongly impact the consumers' purchase intention and eWOM. Thereby, the personality of influencers is slightly affected. They determine that consumers are more likely to recommend a product or services of a company that their following influencers have advertised on their different social media channels. Finlay, we conclude that this study added literature by acknowledging social media influencers significantly impact the consumers' purchase intention and eWOM. Thus, brands and advertising professional could design their marketing activities considering endorsements with social media influencers.

\section{The Acknowledgment}

This paper is initiated with the support of the project Erasmus+ Program Capacity Building for Higher Education of European Union [Reference No. 610455-EPP-1-2019-1-MY-EPPKA2CBHE-JP- Master Degree in Industry 4.0 (Ind 4.0)].

\section{Reference}

Abbas, J., Mahmood, S., Ali, H., Raza, A. M., Ali, G., Aman, J., \& Nurunnabi, M. (2019). The effects of corporate social responsibility practices and environmental factors through a moderating role of social media marketing on sustainable performance of business firms. Sustainability, 11(12), 3434.

Ahmad, S. A., \& Bruno, D. E. (2021). Social Media Influencers and The Dietary Choices Among University Students. Malaysian Journal of Social Sciences and Humanities (MJSSH), 6(10), 543-557.

Ahmed, M., Khan, S., \& Alzughaibi, D. (2021). The Impact Of Snapchat Makeup Influencers On The Consumption Behavior Of Female Students In Saudi Arabia: The Case Of Sephora. Palarch's Journal Of Archaeology Of Egypt/Egyptology, 18(16), 406-414.

Al-Nasser, A., \& Mahomed, A. S. B. (2020). Effect Of Social Media Influencers On Purchase Intentions Of Saudi Arabia Consumers: Instagram As An Evaluation Tool. International Journal of Management (IJM), 11(7). 
Almalki, S., Alghamdi, R., Sami, G., \& Alhakami, W. (2021). Social Media Security and Attacks. International Journal of Computer Science \& Network Security, 21(1), 174-183.

Anuar, N. I. M., Mohamad, S. R., Zulkiffli, W. F. W., Hashim, N. A. A. N., Abdullah, A. R., Rasdi, A. L. M., ... \& Abdullah, S. S. (2020). Impact Of Social Media Influencer On Instagram User Purchase Intention Towards The Fashion Products: The Perspectives Of Students. European Journal of Molecular \& Clinical Medicine, 7(8), 2589-2598.

Arriagada, A., \& Ibáñez, F. (2020). "You need at least one picture daily, if not, you're dead": Content creators and platform evolution in the social media ecology. Social Media+ Society, 6(3), 2056305120944624.

Bhattacharyya, K., \& Debata, B. R. (2021). Measuring the Effectiveness of Social Media in a B2B Scenario in India. Transnational Marketing Journal, 9(2), 285-300.

Bilal, M., Jianqiu, Z., Dukhaykh, S., Fan, M., \& Trunk, A. (2021). Understanding the Effects of eWOM Antecedents on Online Purchase Intention in China. Information, 12(5), 192.

Bonnevie, E., Rosenberg, S. D., Kummeth, C., Goldbarg, J., Wartella, E., \& Smyser, J. (2020). Using social media influencers to increase knowledge and positive attitudes toward the flu vaccine. Plos one, 15(10), e0240828.

Carr, C. T., \& Hayes, R. A. (2015). Social media: Defining, developing, and divining. Atlantic journal of communication, 23(1), 46-65.

Chatterjee, S., \& Kar, A. K. (2020). Why do small and medium enterprises use social media marketing and what is the impact: Empirical insights from India. International Journal of Information Management, 53, 102103.

Chekima, B., Chekima, F. Z., \& Adis, A. A. A. (2020). Social Media Influencer in Advertising: The Role of Attractiveness, Expertise and Trustworthiness. Journal of Economics and Business, 3(4).

Chetna kudeshia Amresh Kumar. (2017)," Social eWOM: Does it affect the brand attitude and purchase intention of brands? ", Management Research Review, Vol. 40 Iss 3 pp. -

Chu, S. C., \& Chen, H. T. (2019). Impact of consumers' corporate social responsibility-related activities in social media on brand attitude, electronic word-of-mouth intention, and purchase intention: A study of Chinese consumer behavior. Journal of Consumer Behaviour, 18(6), 453-462.

Cole III, W. W., Perez-Chaumont, A., Miskimin, C., \& Mulcahey, M. K. (2021). Social Media and Its Use in Orthopaedic Surgery Resident Education and Training. JBJS reviews, 9(11), e21.

Confente, I., \& Vigolo, V. (2018). Online travel behaviour across cohorts: The impact of social influences and attitude on hotel booking intention. International Journal of Tourism Research, 20(5), 660-670.

Dhanesh, G. S., \& Duthler, G. (2019). Relationship management through social media influencers: Effects of followers' awareness of paid endorsement. Public Relations Review, 45(3), 101765.

Global Media Insight. (2021). Saudi Arabia Social Media Statistics 2021. Retrived from: https://www.globalmediainsight.com/blog/saudi-arabia-social-media-statistics/

Glucksman, M. (2017). The rise of social media influencer marketing on lifestyle branding: A case study of Lucie Fink. Elon Journal of undergraduate research in communications, 8(2), 77-87.

Gunnarsson, L., Folkestad, A., \& Postnikova, A. (2018). Maybe Influencers Are Not Worth The Hype: An explanatory study on influencers' characteristics with perceived quality and brand loyalty. 
Guping, C., Cherian, J., Sial, M. S., Mentel, G., Wan, P., Álvarez-Otero, S., \& Saleem, U. (2021). The relationship between csr communication on social media, purchase intention, and e-wom in the banking sector of an emerging economy. Journal of Theoretical and Applied Electronic Commerce Research, 16(4), 1025-1041.

Hale, J. L., Householder, B. J., \& Greene, K. L. (2002). The theory of reasoned action. The persuasion handbook: Developments in theory and practice, 14(2002), 259-286.

Ham, C. D., Lee, J., \& Lee, H. S. (2014). Understanding consumers' creating behaviour in social media: an application of uses and gratifications and the theory of reasoned action. International Journal of Internet Marketing and Advertising, 8(4), 241-263.

Hu, H., Zhang, D., \& Wang, C. (2019). Impact of social media influencers' endorsement on application adoption: A trust transfer perspective. Social Behavior and Personality: an international journal, 47(11), 1-12.

Huhmann, B. A., \& Limbu, Y. B. (2016). Content and compliance of pharmaceutical social media marketing. Marketing Intelligence \& Planning.

Hurley, Z. (2019). Imagined affordances of Instagram and the fantastical authenticity of female Gulf-Arab social media influencers. Social Media+ Society, 5(1), 2056305118819241.

lankova, S., Davies, I., Archer-Brown, C., Marder, B., \& Yau, A. (2019). A comparison of social media marketing between B2B, B2C and mixed business models. Industrial Marketing Management, 81, 169-179.

Jiménez-Castillo, D., \& Sánchez-Fernández, R. (2019). The role of digital influencers in brand recommendation: Examining their impact on engagement, expected value and purchase intention. International Journal of Information Management, 49, 366-376.

Jones, A. H. G. (2020). Using the theory of reasoned action to examine faculty intentions to use social networking in distance learning courses (Doctoral dissertation, University of Alabama Libraries).

Kala, D., \& Chaubey, D. S. (2018). The effect of eWOM communication on brand image and purchase intention towards lifestyle products in India. International Journal of Services, Economics and Management, 9(2), 143-157.

Kay, S., Mulcahy, R., \& Parkinson, J. (2020). When less is more: the impact of macro and micro social media influencers' disclosure. Journal of Marketing Management, 36(3-4), 248278.

Kim, J., Namkoong, K., \& Chen, J. (2020). Predictors of online news-sharing intention in the US and South Korea: An application of the theory of reasoned action. Communication Studies, 71(2), 315-331.

Kim, S., Jiang, J. Y., Nakada, M., Han, J., \& Wang, W. (2020, April). Multimodal post attentive profiling for influencer marketing. In Proceedings of The Web Conference 2020 (pp. 2878-2884).

Lee, J., Ham, C. D., \& Kim, M. (2013). Why people pass along online video advertising: From the perspectives of the interpersonal communication motives scale and the theory of reasoned action. Journal of Interactive Advertising, 13(1), 1-13.

Licoppe, C., \& Smoreda, Z. (2005). Are social networks technologically embedded?: How networks are changing today with changes in communication technology. Social networks, 27(4), 317-335.

Lou, C., \& Yuan, S. (2019). Influencer marketing: how message value and credibility affect consumer trust of branded content on social media.Journal of Interactive Advertising, 19(1), 58-73. 
Madden, T. J., Ellen, P. S., \& Ajzen, I. (1992). A comparison of the theory of planned behavior and the theory of reasoned action. Personality and social psychology Bulletin, 18(1), 39.

Muda, M., \& Hamzah, M. I. (2021). Should I suggest this YouTube clip? The impact of UGC source credibility on eWOM and purchase intention. Journal of Research in Interactive Marketing.

Nafees, L., Cook, C. M., \& Stoddard, J. E. (2020). The Impact of the Social Media Influencer Power on Consumer Attitudes toward the Brand: The Mediating/Moderating Role of Social Media Influencer Source Credibility. Atlantic Marketing Journal, 9(1), 3.

Nisa, E. F. (2018). Creative and lucrative Da'wa: the visual culture of Instagram amongst female Muslim youth in Indonesia. Asiascape: Digital Asia, 5(1-2), 68-99.

Ozgen, P., \& Mahmoudian, A. B. (2021). Examining the Effects of Blogger Type (Influencers vs. Celebrities) and Post Format in Instagram Marketing. In Handbook of Research on New Media Applications in Public Relations and Advertising (pp. 121-132). IGI Global. Permanent link to this document: http://dx.doi.org/10.1108/MRR-07-2015-0161.

Pescaroli, G., Velazquez, O., Alcántara-Ayala, I., Galasso, C., Kostkova, P., \& Alexander, D. (2020). A likert scale-based model for benchmarking operational capacity, organizational resilience, and disaster risk reduction. International Journal of Disaster Risk Science, 11, 404-409.

Plidtookpai, N., \& Yoopetch, C. (2021). The electronic Word-of-Mouth (eWOM) trustworthiness, brand image and other determinants of purchase intention of the middle class to luxury hotel services. Kasetsart Journal of Social Sciences, 42(1), 61-68.

Pookulangara, S., Hawley, J., \& Xiao, G. (2011). Explaining multi-channel consumer's channelmigration intention using theory of reasoned action. International Journal of Retail \& Distribution Management.

Pornsrimate, K., \& Khamwon, A. (2020). Building Brand Evangelism through Social Media Micro-Influencers: A Case Study of Cosmetic Industry in Thailand. International Journal of Social Science Research, 2(3), 84-99.

Pratt, M., Sarmiento, O. L., Montes, F., Ogilvie, D., Marcus, B. H., Perez, L. G., ... \& Lancet Physical Activity Series Working Group. (2012). The implications of megatrends in information and communication technology and transportation for changes in global physical activity. The Lancet, 380(9838), 282-293.

Prayogo, R. R., Ketaren, F. L. S., \& Hati, R. M. (2016, November). Electronic word of mouth, destination image, and satisfaction toward visit intention: An empirical study in Malioboro Street, Yogyakarta. In 1st International Conference on Social and Political Development (ICOSOP 2016). Atlantis Press.

Ramayah, T., Cheah, J., Chuah, F., Ting, H., \& Memon, M. A. (2018). Partial least squares structural equation modeling (PLS-SEM) using smartPLS 3.0.

Ramayah, T., Yeap, J. A., Ahmad, N. H., Halim, H. A., \& Rahman, S. A. (2017). Testing a confirmatory model of Facebook usage in SmartPLS using consistent PLS. International Journal of Business and Innovation, 3(2), 1-14.

Reagan, R., Filice, S., Santarossa, S., \& Woodruff, S. J. (2020). \# ad on Instagram: Investigating the Promotion of Food and Beverage Products. The Journal of Social Media in Society, 9(2), 1-28.

Ringle, C. M., Sarstedt, M., Mitchell, R., \& Gudergan, S. P. (2020). Partial least squares structural equation modeling in HRM research. The International Journal of Human Resource Management, 31(12), 1617-1643. 
Rishika, R., Kumar, A., Janakiraman, R., \& Bezawada, R. (2013). The effect of customers' social media participation on customer visit frequency and profitability: an empirical investigation. Information systems research, 24(1), 108-127.

Rosara, N. A., \& Luthfia, A. (2020). Factors Influencing Consumer's Purchase Intention on Beauty Products in Youtube. The Journal of Distribution Science, 18(6), 37-46.

Rothe, H., \& Wicke, S. (2018). Content-Influencer-Fit: Improving Reach and Impact of Content for Influencers in eWOM. In Proceedings of Multikonferenz Wirtschaftsinformatik.

Saima, \& Khan, M. A. (2020). Effect of social media influencer marketing on consumers' purchase intention and the mediating role of credibility. Journal of Promotion Management, 27(4), 503-523.

Saleem, M., Kamarudin, S., Shoaib, H. M., \& Nasar, A. (2021). Retail Consumers' Behavioral Intention to Use Augmented Reality Mobile Apps in Pakistan. Journal of Internet Commerce, 1-29.

Sarstedt, M., \& Cheah, J. H. (2019). Partial least squares structural equation modeling using SmartPLS: a software review.

Sarver, V. T. (1983). Ajzen and Fishbein's" theory of reasoned action": A critical assessment.

Shan, Y., Chen, K. J., \& Lin, J. S. (2020). When social media influencers endorse brands: The effects of self-influencer congruence, parasocial identification, and perceived endorser motive. International Journal of Advertising, 39(5), 590-610.

Sheppard, B. H., Hartwick, J., \& Warshaw, P. R. (1988). The theory of reasoned action: A metaanalysis of past research with recommendations for modifications and future research. Journal of consumer research, 15(3), 325-343.

Shimp, T. A., \& Kavas, A. (1984). The theory of reasoned action applied to coupon usage. Journal of consumer research, 11(3), 795-809.

Singh, J., Crisafulli, B., \& Xue, M. T. (2020). 'To trust or not to trust': the impact of social media influencers on the reputation of corporate brands in crisis. Journal of Business Research, 119, 464-480.

Slamet, R. F. (2019). Celebrity entrepreneurs vs social media influencers: an analysis of the interplay of endorser type and e-WOM valence on consumers' purchase intention (Master's thesis, University of Twente).

Stubb, C., \& Colliander, J. (2019). "This is not sponsored content"-The effects of impartiality disclosure and e-commerce landing pages on consumer responses to social media influencer posts. Computers in Human Behavior, 98, 210-222.

Sulthana, A. N., \& Vasantha, S. (2019). Influence of electronic word of mouth eWOM on purchase intention. International Journal of Scientific \& Technology Research, 8(10), 15.

Tien, D. H., Rivas, A. A. A., \& Liao, Y. K. (2019). Examining the influence of customer-tocustomer electronic word-of-mouth on purchase intention in social networking sites. Asia Pacific Management Review, 24(3), 238-249.

Vallerand, R. J., Deshaies, P., Cuerrier, J. P., Pelletier, L. G., \& Mongeau, C. (1992). Ajzen and Fishbein's theory of reasoned action as applied to moral behavior: A confirmatory analysis. Journal of personality and social psychology, 62(1), 98.

Weaver, B., Lindsay, B., \& Gitelman, B. (2012). Communication technology and social media: Opportunities and implications for healthcare systems. Online J Issues Nurs, 17(3).

Weismueller, J., Harrigan, P., Wang, S., \& Soutar, G. N. (2020). Influencer endorsements: How advertising disclosure and source credibility affect consumer purchase intention on social media. Australasian marketing journal, 28(4), 160-170. 
Wiedmann, K.-P., \& Von Mettenheim, W. (2021), "Attractiveness, trustworthiness and expertise - social influencers' winning formula?", Journal of Product \& Brand Management, Vol. 30 No. 5, pp. 707-725. https://doi.org/10.1108/JPBM-06-2019-2442

Yoo, W., Yang, J., \& Cho, E. (2016). How social media influence college students' smoking attitudes and intentions. Computers in Human Behavior, 64, 173-182.

Yusuf, A. S., \& Busalim, A. H. (2018). Influence of e-WOM engagement on consumer purchase intention in social commerce. Journal of Services Marketing.

Zeng, C. F., \& Seock, Y. K. (2019). Chinese consumers' perceptions toward social media platform for shopping and eWOM intention: a study of WeChat. International Journal of Fashion Design, Technology and Education.

Zhou, S., Barnes, L., McCormick, H., \& Cano, M. B. (2021). Social media influencers' narrative strategies to create eWOM: a theoretical contribution. International Journal of Information Management, 59, 102293.

Zuhdi, S., Daud, A., Hanif, R., Nguyen, P. T., \& Shankar, K. (2019). Role of Social Media Marketing in the Successful Implementation of Business Management. International Journal of Recent Technology and Engineering, 8. 